\title{
プロテアーゼ処理羊毛の染色性
}

\author{
京都工芸峨維大学工芸学部 柳 章 美・田中 康子・脇田登美司
}

\section{DYEING PROPERTY OF WOOL TREATED WITH PROTEASE}

\author{
Jangmi Ryu, Yasuko Tanaka, and Tomiji Wakida \\ Department of Chemistry and Materials Technology, Faculty of Engineering and Design. \\ Kyoto Institute of Technology, Matsugasaki, Sakyo-ku, Kyoto, 606 Japan
}

\begin{abstract}
Merino wool fibers were treated with neutral protase which is a kind of enzyme to decompose protein. The surface structure of the fibers was observed using a scanning electron microscope. Weight loss by the treatment and the influence of the treatment on dyeing with acid dyes were also investigated. Although the fibers received almost no damage by the treatment in short time and weight loss was negligibly small, rate of dyeing was increased by the treatment. From these results, it seemed likely that the structural relaxation of interscale micellar substance facilitated the dye penetration into the fibers.
\end{abstract}

(Received March 29, 1991)

\section{1. 腥官}

染色加工への酵素の利用は，パパインによる綃の精練 などが古くから行われて来た。洗戍への䣼素の添加 [1] をはじめ，最近はセルロース分解醭素セルラーゼによる 本綿の隇量加工が関心を集め，綿布の柔軟化を目的とし た風合加工が赛用化されている[2]。羊毛のブロテアー せ处理による改質もすでにいくつか報告されている [3-5]。本研究ではメリノ羊毛轼維を非限定タンパク質 分解䣼素中性ブロテアーゼで処理した場合の走査型電子 影微鏡に上る表面状態の観察，重量隇少率，および酸性 染料による染色性などについて検討した。

\section{2. 実殹方法}

試料としてメリノ羊毛トップを用いトルエンエエタ， 一ルでそれぞれ10時間ソックスレーで抽出した。これを タンバク質分解醭素として非限定分解型中性プロテアー ゼ(プロチンPS-10，協和発醉)を使用し，pH $7.0010 \%$ o.w.1. 水溶液で, 浴比 $20: 1,50^{\circ} \mathrm{C}$ で $1 ， 2 ， 5$ 時間处理 した後，蒸留水で繰り返し洗浄した。これを日立製作所 震電界故射形走查電子影微鏡 S-800を使用し，500倍々 3000倍で表面状態を钼察した。また $1 ， 2 ， 5$ 時間処理し た場合の重量減少率を誦べた。さらにこれらの羊毛につ い下, 均染型酸性染料 Orange I(C. I. Acid Orange 7)
ミリング型酸性染料 Kayanol Milling Cyanine 5R(C. I Acid Blue 113)の10\% o.w.f. 染浴を, $\mathrm{KH}_{2} \mathrm{PO}_{4}$ と $\mathrm{Na}_{2} \mathrm{HPO}_{4}$ の緩衝溶液で $\mathrm{pH} 4.3$ 抢上び5.5に調整した後，浴比 1 ： $1000 ， 60^{\circ} \mathrm{C}$ で時間を变之て染色した。染色後25\%ピリ

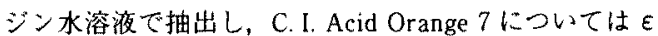
$=1.937 \times 10^{4}, \lambda_{\max }=485 \mathrm{~nm}$ で, C. 1. Acid Blue $113 \mathrm{k}$ ついては $\varepsilon=3.256 \times 10^{4}, \quad \lambda_{\max }=595 \mathrm{~nm}$ で比色定量に よって染着量を求めた（ $\varepsilon$ : 分子吸光保数、 $\lambda_{\text {max }}$ : 最大 吸収波長)。

\section{3. 結果と考察}

\section{1 走䅦型電子影徽鏡による表面の钼宗}

ブロテアーゼ処理した羊毛の電子顕微鏡写真を図 1 に 示した。500倍では織維集合体としてみた場合の全体的 な損㩐の状態さ，さらに3000倍では一本の䄉維の損傷の 状態を観察した。未処理羊毛ではスケールの損偒は全く 認められなかった。2 時間処理した場合も全体的に目立 った変化は認められなかったが, 部分的にスケールが深 き上がり，スゲール剥離の前駆的な状態が㷵められた。

5 時間起理した場合は，全く損傷の受けていない部分 も多いが，部分的には明らかにスケールの煣離が起り， コルテックスが露出し，さらにフィブリル化の進んでい る部分も認められた。

これらの結果から、プロテアーゼ処理によって羊毛の 

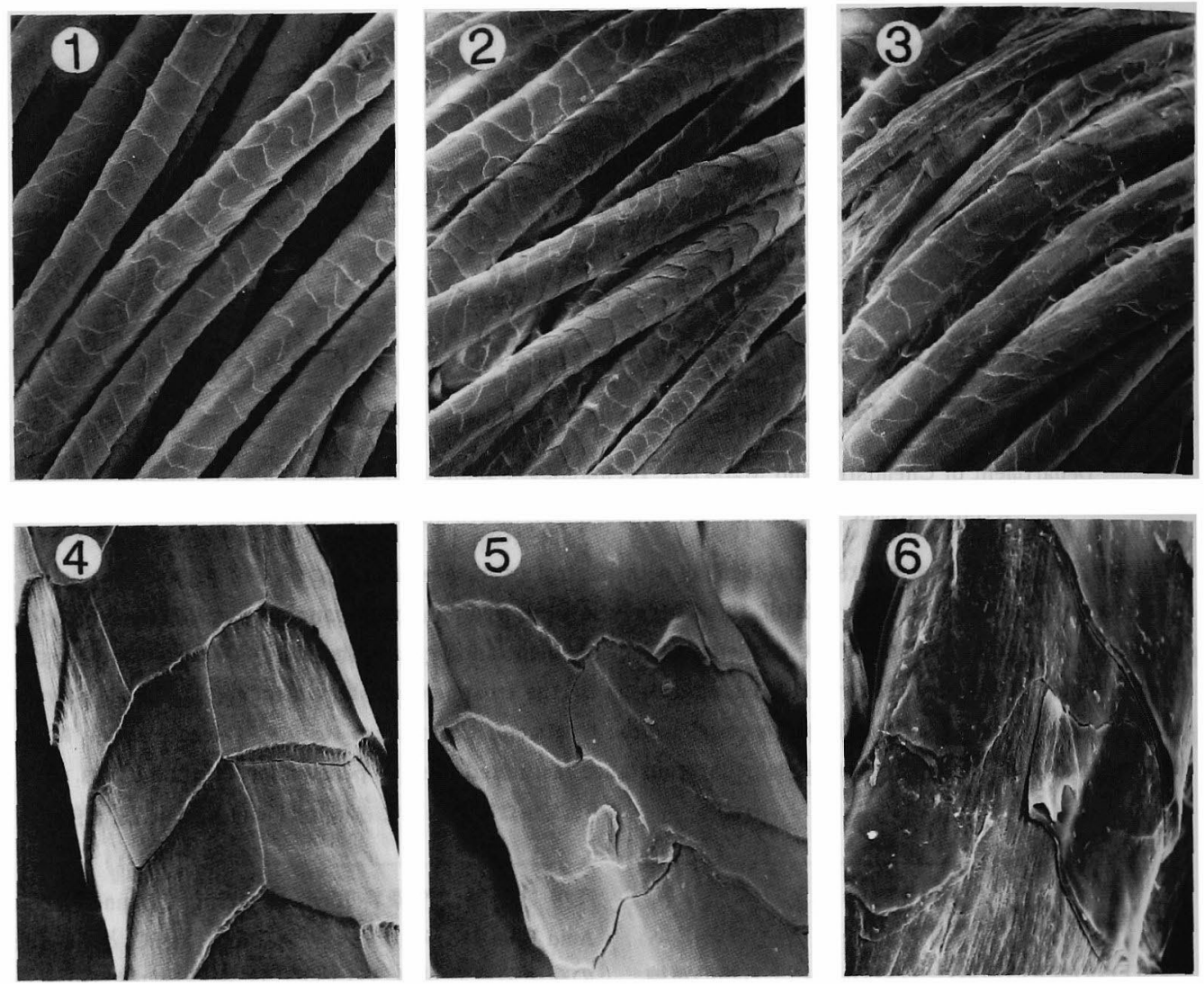

Fig. 1. SEM photographs of protease-treated wool $(\times 500$ and $\times 3000)$. Protease treatment was carried out with $10 \%$ o.w.f., at $60^{\circ} \mathrm{C}$ for 0,2 , and $5 \mathrm{~h}$, respectively. (1) and (4) untreated; (2) and (5), $2 \mathrm{~h}$; (3) and (6), $5 \mathrm{~h}$.

表面全体が一様に分解されるのではなく，表面のごくわ ずかな損傷部分から細胞間接着層にプロテアーゼが浸透 して酵素反応が進み，構造弛緩と部分的なスケールの剝 離, さらにコルテックスのフィブリル化が起り, 緎維の 部分的な損傷が加速されたと考えられる。

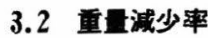

羊毛織維のプロテアーゼ処理によって細胞間接着層の 分解, スケールの剥離, 脱落によって重量隇少が起ると 考えられる。pH $7.0010 \%$ o.w.f. プロテアーゼ水溶液で 1-5 時間処理した場合の重量隇少率を表 1 に示した。

Table 1 Weight Loss of Wool by Protease Treatment

\begin{tabular}{ccccc}
\hline & \multicolumn{4}{c}{ Time of protease treatment } \\
\cline { 2 - 5 } & $1 \mathrm{~h}$ & $2 \mathrm{~h}$ & $3 \mathrm{~h}$ & $5 \mathrm{~h}$ \\
\hline Weight loss $(\%)$ & 0.36 & 0.67 & 1.22 & 2.57 \\
\hline
\end{tabular}

重量減少率は処理時間とともに増加する傾向にあるが， 2 時間までは約 $1 \%$ 以下の無視できる程度で， 5 時間て も約 $2.5 \%$ あっった。

\section{3 染色性}

1，2，5時間プロテアーゼ処理した羊毛の C.1. Acid Orange 7 と C. I. Acid Blue 113の染色速度曲線索园2に 示した。プロテアーゼ処理によって染着量が增大するが (5), プロテアーゼ処理時間が長くなるほど, 染着量が 増大した。2 時間のプロテアーゼ処理では, SEMによる 観察から織維表面の損傷がほとんど認められないにも㧦 わらず染色速度が著しく增大した。これを $\sqrt{t}$ $\mathrm{C}_{\mathrm{t}} / \mathrm{C}_{\infty}$ に書き変えると図 3 が得られた。染色速度(直得 の勾配)は処理時間が長いほど速くなった。とりかけミ リンク型染料の染色速度增大の傾向が大きくなった。染 色速度曲線から求めた半染時間を表 2 に示した。またフ ロテアーせ処理羊毛の飽和染着量を表 3 に示した。2時 間までのプロテアーゼ処理でも染色速度が增大した。2 

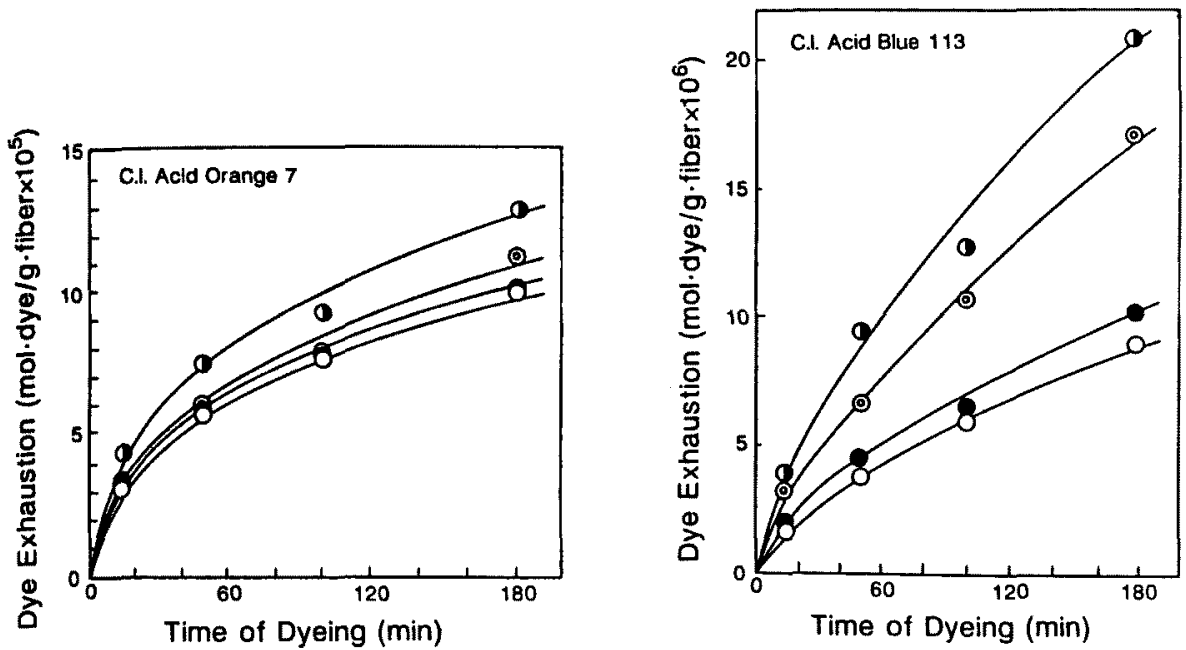

ig. 2. Relationship between dye exhaustion and dyeing time for C. I. Acid 7 and C. I. Acid Blue 113. Protease treatent was made at $60^{\circ} \mathrm{C}$ for 1,2 , and $5 \mathrm{~h}$, respectively. Untreated (O), $1 \mathrm{~h}(\mathrm{O}), 2 \mathrm{~h}(\mathrm{O})$, and $5 \mathrm{~h}(\mathrm{O})$.
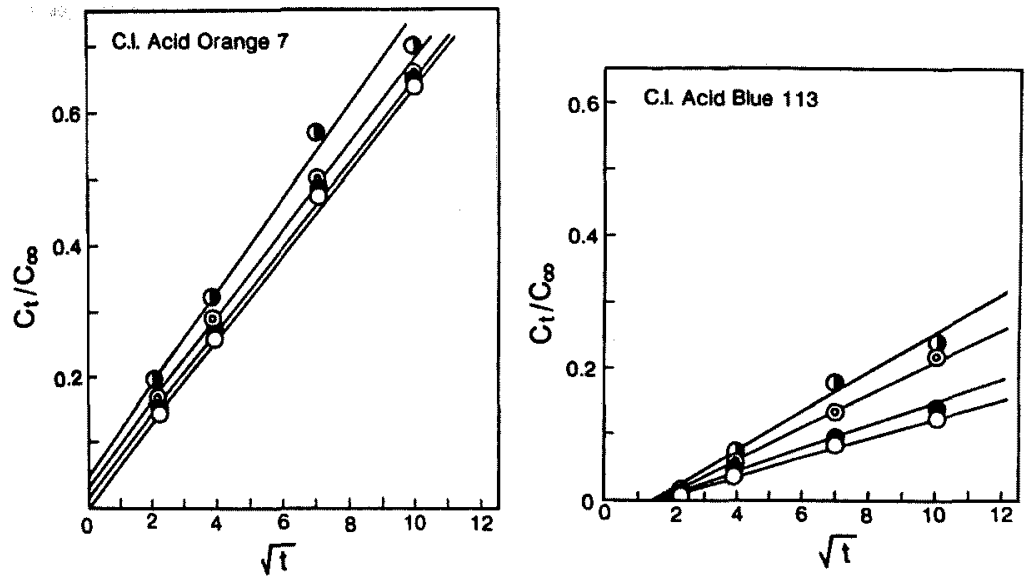

ig. 3. Relationship between $\mathrm{C}_{\mathrm{t}} / \mathrm{C}_{\infty}$ and $\sqrt{\mathrm{t}}$ for C. I. Acid 7 and C. I. Acid Blue 113. Protease treatment was made at $0^{\circ} \mathrm{C}$ for 1,2 , and $5 \mathrm{~h}$, respectively. Untreated $(\mathrm{O}), 1 \mathrm{~h}(\mathrm{O}), 2 \mathrm{~h}(\mathrm{O})$, and $5 \mathrm{~h}(\mathrm{O})$.

rable 2 Time of Half Dyeing of Protease-treated Wool

\begin{tabular}{crrrr}
\hline & \multicolumn{4}{c}{ Time of half dyeing $(\mathrm{min})$} \\
\cline { 2 - 5 } Dye & \multicolumn{4}{c}{ Time of protease treatment } \\
& Untreated & $1 \mathrm{~h}$ & $2 \mathrm{~h}$ & $5 \mathrm{~h}$ \\
\hline 1. Acid Orange 7 & 64 & 52 & 50 & 39 \\
l. Acid Blue 113 & 869 & 849 & 475 & 380 \\
\hline
\end{tabular}

Table 3 Saturated Dye Exhaustion of Protease-treated Wool

\begin{tabular}{lcccc}
\hline \multirow{2}{*}{ Dye } & \multicolumn{5}{c}{ Saturated dye exhaustion $\left(\right.$ mol.dye/g.fiber $\left.\times 10^{4}\right)$} \\
\cline { 2 - 5 } & Untreated & $1 \mathrm{~h}$ & $2 \mathrm{~h}$ & $5 \mathrm{~h}$ \\
\hline C. I. Acid Orange 7 & 2.08 & 2.06 & 2.05 & 2.13 \\
C.I. Acid Blue 113 & 1.07 & 1.14 & 1.20 & 1.34 \\
\hline Dyeing was carried out at $\mathrm{pH} 4.3$ and temperature of 60 \\
${ }^{\circ} \mathrm{C}$ for $120 \mathrm{~h}$ with $\mathrm{C}$. I. Acid Orange 7 . and at pH 5.5 and \\
temperature of $60^{\circ} \mathrm{C}$ for $360 \mathrm{~h}$ with $\mathrm{C}$. I. Acid Blue 113.
\end{tabular}


時間のプロテアーゼ拠理では轼維はほとんど損揚を受け ていないので，染色速度の増大はプロテアーゼによって スケールの細胞間接着看の構造か驰楥されるために染料 の移動が起り易くなったと考えられる。一方飽和染着量 は均染型酸性染料 C. I. Acid Orange 7 につては,プロ テアーせ処理によってほとんど変化は認められないが, ミリング型酸性染料 C. I. Acid Blue 113の場合は处理時 間が長くなるにしたがって，釉 $20 \%$ 的和染着量の增大が 認められた。同様な䅳和染着量增大の効果は羊毛を酸素 あるいはテトラフルオロメタンで短時間低温ブラズマ処 理した場合にも認められた 6 的。1 分間の短時間低温プ ラズマ处理ではスケールの損傷は全く認められないにも 拘わらず染色速度が速くなり，とりわけミリング型酸性 染料の飽和染着量が著しく增大した。

この様に短時間のプロテアーゼ㚭理によるミリング型 染料の盷和染着量の增大は，細胞間接着層のわずかな構 造弛縟によって，染料の移動が促進され，織維内部に浸 透した染料のイオン結合による染着以外に，水素結合や 疎水性結合などによる染着が增え，全体的に飽和染着量 增大に奇与したと考えられる。この点についてはさらに
検討中である。

\section{4. 結 論}

羊毛のプロテアーゼ処理によって，染色性とりかけミ リング型酸性染料の平衡染着量が增大した。しかし走直 電子顕微鏡による観察では，処理時間が 2 時間まではは とんど織維の損傷が認められなかった。これより緗狍間 接着層のわずかな構造弛緩が染色速度の增大に大きく関 与していると考えられる。

\section{女献}

1. G. Jakobi, A. Lohr, "Detergents and Texile Washing", p. 87 (1987)

2. 谷田 治，染色工業，37, 122 (1989)

3. H. R. Haefely, Textilveredlung, 25, 271 (1989)

4. A. Riva, J. Cagarra, and R. Prieto, Proc. 15th Int. Text. Chem. Color. Conf., (1990)

5. 東洋紡縝(株)，特公昭 58-48669

6. 柳 章美，脇田登美司，李 文瀧，械学誌投稿中 (No. 91027) 